\title{
Financial Services
}

\section{Conflicts of interest: the challenge to courts and regulators by George Barboutis}

The conflict of interest is a very common concept arising in a multiplicity of contexts in business life where:

\footnotetext{
'... two or more interests are legitimately present and competing or conflicting, while the individual making a decision that will affect those interests may have a larger stake in one of them than in other $(s)^{\prime}$.
}

(Schotland Roy, Introduction to the Twentieth Century Fund Steering Committee on Conflicts of Interest in the Securities Markets, Abuse on Wall Street: Conflicts of Interest in the Securities Markets, Westport, Conn., Quorum Books, 1980, at 5).

The concept of conflict of interest, or conflict of duties, has also been approached as one arising:

'...whenever one is serving two or more interests and can put one person in a better position at the expense of another'.

(FR Eswards, 'Banks and Securities Activities: Legal and Economic Perspectives on The Glass-Steagall Act', in LG Goldberg and LT White (eds), The Deregulation of the Banking and Securities Industries, Lexington, Toronto, 1980, at 282.)

These definitions are structured on the basis of two elements: on the one hand, the existence and conflict of two or more competing interests and, on the other, the position (and the dilemma) of a person whose duty it is to balance these interests and finally resolve their conflict by promoting only one of them at the expense of the others. Given that the decision on which interest to promote is one resting upon the discretionary power of one sole person and his own personal integrity and criteria, one might reasonably expect such a decision not to be perfectly impartial, but to some extent influenced by the person's own preferences and interests. Furthermore, at this point we may introduce the third: the additional parameter of interdependence of interests - the factor which may affect in a determinative way the deciding person's discretion and, hence, the very resolution of the conflict itself.

\section{EQUITY AND CONFLICT: BASIC RULES}

The framework of rules applying to the problem of conflicts of interest and their resolution was built on the basis of the rules governing the nature and operation of the fiduciary relationship. The rules on fiduciaries and fiduciary obligations have evolved through time, starting from a general catch-all duty of the fiduciary to act in the best interests of the beneficiary and developed to a framework of prohibitive rules which stipulate the actions which fiduciaries cannot take, the factors by which the fiduciaries cannot be influenced and the results that the fiduciaries' actions cannot have.

This was named 'the proscriptive orthodoxy of Anglo-Australian fiduciary law' John Glover, Commercial Equity: Fiduciary Relations, Butterworths, Adelaide, 1995, at 2), and was summarised by Lord Herschell in 1896 as:

\section{[one] inflexible rule of a Court of}

Equity: that a person in a fiduciary position is not, unless otherwise expressly provided, entitled to make a profit; he is not allowed to put himself in a position where his duty and interest conflict.' (Bray v Ford [1986] AC 44 at 57)

Tn a long series of court decisions this fundamental proscriptive approach was repeated and analysed on many occasions and in various wordings and formulations, such as: fully informed consent apart, an agent cannot lawfully place himself in a position in which he owes a duty to another which is inconsistent with his duty to the principal...' (North \& South Trust Co v Berkeley [1971] 1 WLR 470 at 484)

and

the duty of a fiduciary is twofold: first where he has undertaken to act for or on behalf of another, he must refrain from letting any personal interest sway him from the proper performance of his undertaking; second, he must not misuse the position of trust his undertaking gives him to further his own interests. He must not profit from his own position of trust'. (Standard Investments Ltd v Canadian Imperial Bank of Commerce (1893) d DLR (4th) 452 at 481 , Griffiths J (Ont. CA))

Thus, the content of the fiduciary obligation is clarified on the basis of two fundamental prohibitions: the 'no-profit and no-conflict' rules.

\section{WHY ARE CONFLICTS SO COMPLEX AND ACUTE?}

The intense pressures of competition have led the key players in the world of financial services such as commercial and investment banks, accounting and consulting firms - to a rapid process of restructuring or in the direction of offering an ever wider variety of more complicated and more 'profitable' financial products and services.

This restructuring process is basically characterised by a qualitative and a quantitative dimension, i.e. a tendency for growth in seize through consolidation, as well as diversification, in the nature of services offered through the combination of various financial functions offering various products.

The aim of consolidation is, on the one hand, to cut down the operating 
costs of the industry and create economies of scale, and, on the other, to create competitive advantages by enlarging as much as possible a firm's clientele - which means both a wider target market for cross-selling, but also a wider spectrum of information possessed by one single firm about market conditions and prospects (which in the financial market means better quality). Similarly, diversification aims to exploit the obvious market advantages of concentrating and offering the widest possible range of products and services in one single financial conglomerate (the so-called 'financial supermarket' or 'money mall').

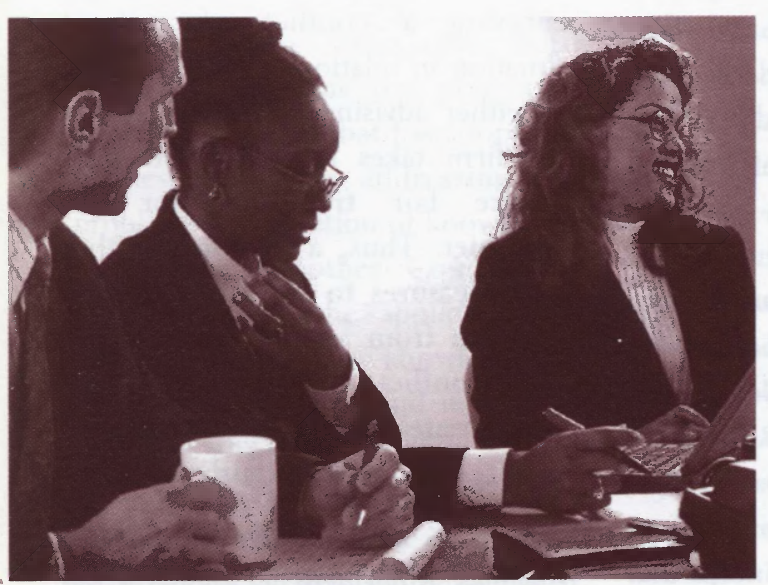

Services and Markets Bill envisages the creation of one single regulatory authority (FSA) supervising all those different sectors is indeed the virtual endorsement of today's universal bank model reality.

On the other hand, in the US the Glass-Steagall Act has for almost a century imposed strict barriers to the approach of the functions of commercial banking, investment banking and insurance. However, for years a strong tendency towards adopting the universal bank model has rapidly grown in the US, which gradually challenged the GlassSteagall Act and finally led to its virtual abolition in November 1999 by the Gramm-LeachBliley Act, which permitted the affiliation of banks with securities firms and insurance companies, expanded the activities permissible to bank affiliates to 'those financial in nature', authorised merchant bank investments in nonfinancial business and reduced the Federal Reserve supervision over

The effects of these tendencies have made a rapid appearance in the sector. After a strong wave of mergers and acquisitions leading to consolidation in the investment banking industry, the global market for financial services is today dominated by a small number of large international investment banks. At the same time, the larger the firms get, the wider the variety of services they offer.

In the absence of restrictive regulation in countries such as the UK and Germany, the dominating model is that of the universal bank providing all kinds of services, ranging from retail and corporate banking, to investment banking, corporate finance services, investment advice, asset management, operation of unit trusts and mutual funds, and even insurance services. The fact that the Financial provide a detailed framework for addressing the problems and I believe that the new rules currently being drafted will be even more efficient);

- the management, transfer and fair allocation of risk between various functions of a conglomerate (i.e. support of a failed securities offering by either the trust management branch (through stock purchases) or by the commercial banking arm of the same firm through imprudent debt financing of the issuer);

- conflicts arising in situations of economic dependence and influence (such as economic tie-ins and interlocking directorships); and

- the so-called 'informational advantages and internal management of information' conflicts (which I consider the most acute and interesting and on which I have chosen to focus the rest of my analysis).

In this latter case, the basic conflict is structured in two stages: the acquisition of 'sensitive' information and the management and transmission of such. Within a financial conglomerate, there are various sources for the acquisition of information. Investment bankers acquire inside information through underwriting, financial restructuring, mergers and acquisitions; cozzzzzorcial baulere orpuire information through the due diligence necessary for the provision of debt financing; generally, a financial conglomerate can gain access to a company's secrets through various other ways, such as the appointment of members on its board of directors, etc. In cases such as the above, the information is usually acquired within the limits of a fiduciary relationship and is thus confidential.

The second stage is the management of this information, which generally has a price-sensitive 
character and thus a wealth generating potential.

Such information may be transmitted throughout the conglomerate to its trust department or trading department, where the firm's traders may transform the informational advantage into a pecuniary benefit for the conglomerate itself, or its investorclients. I will not deal with any issues of insider trading that arise in this context.

\section{THE CHINESE WALL}

The basic structural means that modern financial conglomerates have adopted to manage conflicts of informational advantages is the Chinese wall, a metaphor describing a set of rules, regulations, procedures and physical arrangements adopted by a firm in order to prevent confidential information from flowing from one of its departments to the other (see Larry Varn, 'The Multi-service Securities Firm and the Chinese Wall: A New Look in the Light of the Federal Securities Code', 63 Nebr L Rev 197, at 210), thus minimising the risk of abuse of this information for the benefit of the firm itself or of other clients who should not be allowed to access it.

A Chinese wall is usually set up in order to separate information-source departments (investment and commercial banking and, possibly, the specialist department) from those which can convert the information into a financial benefit for the firm or its clients, such as the securities trading or the trust department. Thus the wall is an internal device, operating within the structure and hierarchy of a firm and affecting virtually only its internal operations.

In general the wall is considered as serving a prophylactic function, in the sense that it prevents the interdepartmental flow of information within the firm. However, its wide adoption in the industry, combined with its encouragement and endorsement by the regulators in the UK and the US, have led to a more sensitive question: whether the wall may also serve as a means towards a legal purpose, that of providing an ex post facto defence for a firm against incurring liability for insider trading or breach of contractual or mainly fiduciary duties to a client from whom the confidential information was acquired. (See Norman Poser, 'Chinese Wall or Emperor's New Clothes?', (1988) 9 Co Law 119.)

However, the issue of the efficiency of the wall as a legal defence is inevitably linked with the legal issue of attribution of corporate knowledge, and in particular whether an efficient wall can shield the firm from attribution of knowledge to it as a whole, in case a piece of material confidential information is held isolated in one department of the firm, without being communicated to others (see the Law Commission Consultation Paper No. 124, 'Fiduciary Duties and Regulatory Rules ('LCCP No. 124'), para. 4.5.1, at 138). The premise of such a rationale is based on the concept that the adoption of adequate procedures of internal control over the access to material non-public information will be an efficient means of preventing the abuse of such information and reducing problems of conflicts of interest. (See Edward Herlihy, 'Insider Trading and Chinese Walls: Is There a Need for Reform?', (1987) 561, PLI/Corp 727, (PLI Order No. B4-6791); also Roy, above, at 212).

\section{THE REGULATORY POSITION}

I shall try to address briefly the regulatory position as at this moment of transition by looking at the old Conduct of Business Rules, with the reminder that the Financial Services and Markets Bill is intended to replace the current FSA 1986 during 2000/2001 (having now received Royal Assent on 14 June) and new regulatory rules are expected to be introduced by the Financial Services Authority and to replace the Core Rules.

Indeed, General Principle 6 states that a firm should either avoid any conflict of interest arising, or should ensure 'fair treatment for all its customers by disclosure, internal rules of confidentiality, declining to act or otherwise', as well as that the firm should not unfairly place its interests above those of its customers, especially where a properly informed customer would not expect it to do so. Apparently 'internal rules of confidentiality' refer to Chinese wall policies. In the same spirit, Core Rule 2 prohibits a firm from knowingly entering a conflict of interest situation in relation to a transaction, by either advising or dealing, unless the firm takes reasonable steps to ensure fair treatment for the customer. Thus, a firm may either take measures to prevent a conflict situation from arising, or deal with the conflict by adopting the appropriate measures for ensuring that its customers are fairly treated.

Rule 36 of the RSA's Conduct of Business Rules actually endorses the Chinese wall as a measure affording protection to a firm without the need to obtain the customer's consent where information has not crossed the wall.

The first paragraph of the rule permits the withholding of information obtained by one part of the firm from the persons with whom it deals (clients) in the course of carrying out another part of its business, as well as those of its employees who are dealing with the same clients in the other part of the firm's business, as long as such parts involve investment or related business. In addition, in its second paragraph, the rule confirms the same rule of isolation of information among different associates of a business group, reiterating that what is known to one company in a group may not be transmitted to other companies of the same group despite any obligations 
imposed by other Core Rules, as long as a Chinese wall policy is in operation (see Michael Blair, Financial Services: The New Core Rules, (Blackstone, London 1991) at 138).

The third and fourth paragraphs to the rule have a supplemental function to the main provisions of the first two paragraphs. Thus, the fourth paragraph reiterates the protection offered to a firm that has adopted a Chinese wall scheme in accordance with the Core Rules against the potential imposition of liability by the anti-fraud provision of s. 47 of the Financial Services Act, mainly operating as an explanation to s. $48(6)$ of the Act.

At the same time, the third paragraph confirms the protection afforded to a firm that has adopted a Chinese wall, by addressing the problem of attribution of knowledge, in relation to other Conduct of Business Rules, the application of which depends upon knowledge on the part of the firm, and it does so through the introduction of a presumption that the firm will not be taken to act in knowledge when none of its employees involved on behalf of it acts with knowledge.

According to the Law Commission Consultation Paper on Fiduciary Duties and Regulatory Rules (LCCP No. 124, para. 4.5.13, at 152), Rule 36 relieves a firm which operates an 'established arrangement' in compliance with it from the obligation of acquiring the customer's consent for the operation of such.

\section{FINANCIAL SERVICES AND MARKETS BILL}

From the early stages of the consultation process it was clarified in the draft documentation (see 'Financial Servies and Markets Bill: A Consultation Document, Part One: Overview of Financial Regulatory Reform', para. 5.11) that:

'[the Bill] will ensure that compliance with FSA rules relating to Chinese walls which manage or avoid conflicts of interest

and help prevent insider dealing, will protect a firm not only against criminal liability, but also civil action for breach of duty. This will mean that firms are not put in risk of legal challenge where they comply with these important regulatory requirements.'

The FSA expressed its intention to address the issue of regulatory endorsement of Chinese walls in the context of Consultation Paper No. 10 dealing with the issue of the drafting of a new Code of Market Conduct. In particular, it is stated that:

'in order to ensure that knowledge of the employees is not imputed inappropriately to the company for the purpose of statutory provisions, the firm is presumed not to be in possession of the information for the purposes of its dealing if it can meet two tests: first, that at all material times effective arrangements were in operation to prevent such information that is in the possession of any other personnel within the firm from influencing the firm's decision to deal with investments and secondly, that

the relevant

information was not in fact known by any of the firm's personnel who were concerned in the decision to deal.'

on the internet http://www.lawcorn.gov.uk/library/lib-crim.htm

Summaries and full texts of the Law Commission's consultation papers are available on this site.

\section{(s. 123)}

Furthermore, it is also made clear that the Chinese wall arrangements should be designed not only to seek to prevent the passage of information but in order to detect when there may have been a breach and to remedy any breach to the extent possible. Finally, in view of the fact that it is impracticable for firms to raise Chinese walls within their trading departments between every trader, it is suggested that other methods of demonstrating effective control of information would be necessary and might involve firms in setting up new systems to evidence information control.

\section{THE COURTS' APPROACH}

We shall now examine the approach of courts to the Chinese wall and the views they have adopted on the main issues of interest, namely the issue of attribution of corporate knowledge to various departments of a firm and, in particular:

- whether it can be admitted from a dogmatic point of view that the Chinese wall can actually cause a crack in the traditional concept of one single corporate knowledge, based on the attribution to one corporate mind of the knowledge held by all the various departments of a firm;

- the adequacy of the Chinese wall as an arrangement which can efficiently stem the interdepartmental flow of confidential information within the context of a given establishment, such as an investment bank, a law firm or an accountancy firm; and

- the efficiency of the Chinese wall as a legal defence to actions for breach of contractual or fiduciary duties.

\section{The issue of corporate knowledge}

The traditional case law concept of attribution of knowledge to the corporate entity is based on the notion that a corporation has one single mind to which any knowledge possessed by all its departments, branches or employees is attributed. Thus, this abstract single corporate mind knows and possesses any information in any part of the firm, however large the firm or however detailed or complex the information may be. Such an approach apparently has significant consequences for the issue of attribution of liability to a company on the basis of knowledge of certain facts for establishing fraud or negligence.

In the context of financial services, a unified mind of an investment bank 
will be deemed to possess all confidential information possessed by its underwriting branch, its specialist branch as well as its M\&A branch. Thus, the investment management or the brokers and dealers branch of an investment bank will be legally considered as being in possession of any confidential information disclosed, i.e. to the employees of the corporate finance department doing a due diligence exercise in a company before the public offering of its securities.

A look at the case law on the matter of attribution of knowledge shows the reluctance of courts to acknowledge any concept that would deviate from the notion of the single and indivisible corporate knowledge. Thus judges had refused to regard separate corporate departments as two separate entities, either insisting that:

'one company is one person in law, however [many] businesses they may carry on' (Harrods Ltd $v$ Lemon [1931] $2 \mathrm{~KB}$ 157),

or holding that:

'a company could not claim to have split up its knowledge' (Lloyds Bank Ltd v EB Savory \& Co [1933] AC 201),

or concluding that:

'even when a company has [been] deemed to have more than one directing mind in the same field of operations, the knowledge, acts and intention of two or more directing minds should be attributable in total to the corporation' (Standard Investments Ltd $v$ Canadian Imperial Bank of Commerce (1986) 22 DLR (4th) 410).

The above decisions were of course formulated in the context of companies which did not operate a Chinese wall establishment.

However, more recent cases such as El Ajou $v$ Dollar Land Holdings plc ([1993] 3 All ER 717 (Millett J); rev'd, CA, [1994] 2 All ER 685), Meridian Global Funds Management Asia Ltd v Securities Commission ([1995] 2 AC 500) and Director General of Fair Trading v Pioneer Concrete (UK) Ltd ([1995] 1 AC 456; [1995] 1 All ER 135), have adopted a context-specific approach by considering persons who, regardless of their positions in the company hierarchy act on behalf of the company in specific transactions, as consequently the ones who represent the company's mind and will in that specific transaction.

On this basis, a company's mind and will is formulated as a contextspecific concept. In view of the vast size and complex structure of firms and the huge number of transactions performed every day or every minute on behalf of a firm in the financial services industry, such a contextspecific approach appears as a fair and possibly necessary mitigation of a stringent and inflexible rule which only causes dogmatic complications.

In any case, trying to attribute to some abstract company brain all the knowledge held by all agents' 'departments' would lead to an absurdum, as on one hand it has now been admitted both from a dogmatic and from a practical and realistic point of view that the mind of a company is not a conceptual metaphor but the actual mind of its agents (and nobody in a firm could be in a position to know practically everything), while on the other hand such a collective attribution would be inconsistent with the context-specific approach, which in terms of corporate liability requires the company mind to be that of the person carrying out the specific transaction on behalf of the company.

So far, the concept of split company knowledge or departmental company knowledge has not been legally endorsed. In the Court of Appeal decision in HRH Prince Jefri Bolkiah $v$ KPMG (The Times, 22 October, 1998), Lord Justice Waller correctly remarked that there would simply be no reason for examining Chinese walls and their effectiveness, if knowledge of one partner is to be imputed to another, thereby placing the other under an embargo from acting. Such an admission by Lord Justice Waller, if considered in connection with the key admissions of case law in respect of the concept of attribution of knowledge, makes quite obvious the need for a reconciliation between the rigid, single corporate mind concept and the need for a legal concept that will formalise (and legalise) what is practically achieved by an adequately operating Chinese wall: the actual division of corporate knowledge, the separation of information between separately operating departments and indeed the concept of split or departmental corporate knowledge.

The above seems to be in line with the current regulatory position under Core Rule 36.3, which, as already analysed, virtually introduces a presumption that the firm will not be taken to act in knowledge when none of its employees involved on behalf of it, acts with knowledge.

I think that in this respect the Conduct of Business Rules actually endorse a form of split or departmental knowledge by way of a presumption which in some way bypasses the application of the aforementioned rigid principles of common law, but nevertheless operates only in relation to particular other Core rules. In any case, by their regulatory nature, the Conduct of Business Rules cannot actually resolve the problem of attribution of knowledge which does, in my opinion, have to be addressed through statutory provisions of the new FSMA.

\section{Adequacy of the Chinese wall}

Before we look at case law on the adequacy of the Chinese wall we have to remark that the main bulk of relevant Commonwealth case law is limited to cases involving law firms and just a few cases of accounting firms, while no investment bank cases have attracted any serious attention on the matter so far.

One should always keep in mind in connection with law firm cases that 
in view of the special nature of the lawyer-to-client relationship and the position of the solicitor as an officer of the court, the approach of courts to the concept of Chinese walls in the law firm context has been fairly strict.

Indeed a significant degree of scepticism characterises the courts' views on how acceptable it may be to allow law firms to act in situations of conflict by representing clients with directly or even potentially conflicting interests and whether a Chinese wall can efficiently protect the confidentiality of information within the same firm and thus preserve the impartiality of action of the firm.

The caution and scepticism with which Commonwealth courts have consistently approached the concept of resolution of a conflict of interest situation in a law firm through the adoption of a Chinese wall is demonstrated by a variety of expressions referring to the wall, such as:

'a scheme which would offend against established principle and indeed the public interests in the proper administration of justice' (Mallesons Stephens Jacques V KPMG Peat Marwick [1990] WAR 357)

or

'the law has a strong policy of insuring that solicitors do not have actual or apparent conflicts of interest in order to obtain public confidence in the administration of justice'. [QUOTE]

(Carindale Country Club Estate Pty Ltd v Astill [1993] 115 ALR 112)

In Supasave Retail v Coward Chance in 1991, the court appeared sufficiently sceptical towards the efficiency of the Chinese wall to remark that 'once the possession of confidential information by a firm of solicitors has been established, the erection of a Chinese wall will be regarded as inadequate protection for the interests of the former client', noting that there is always an element of seepage of confidential information in a firm or a group through casual chatter and discussion. (David Lee \&
Co (Lincoln) Ltd v Coward Chance and Ors; Supasave Retail Ltd v Coward Chance (a Firm) and Ors [1991] Ch 259; [1990] 3 WLR (2) 1278; [1991] 1 All ER 668.)

Besides, in 1992 the court refused to accept the mere existence of a Chinese wall as a sufficient condition for the satisfaction of the confidentiality requirement; the judge expressed his strong reservations as to whether an impregnable Chinese wall could ever be created and added that only in very special cases should any attempt should be made to do so (Re a firm of Solicitors [1992] 1 All ER 353).

A more modest and tolerant approach to the adequacy of the Chinese wall was formed in the more recent decision of the New Zealand Court of Appeal in Russell McVeagh $v$ Tower Corporation (Russell McVeagh McKenzie Batlett $v$ Tower Corporation, New Zealand Court of Appeal, 27.09.1998) in which the court formed an efficiency test which looks at the particular circumstances of the specific context in order to identify whether an unacceptable risk of communication of confidential information exists.

The court adopted a test based on three questions in particular:

- whether confidential information is held which, if disclosed, may affect the former clients interests;

- whether there is a real or appreciable risk that such information will be disclosed ; and

- whether the discretionary power of the court to intervene should be exercised in view of the significance of the special fiduciary relationship.

Before we turn to the approach adopted in Prince Jefri, we should reiterate that in view of the special nature of the solicitor's position, the courts should be very cautious in adopting the principles formulated in law firm cases to different contexts, such as that of financial services.
It is a fact that, so far, the authorities on the issue of the adequacy of the Chinese wall are limited to the law firm context. However, a direct transfer of principles applicable to law firms to a different context such as that of an investment bank or an accounting firm could give rise to problems of inconsistency. The difficulty involved in applying solicitors' Chinese walls precedents to different contexts becomes obvious to the reader of the Prince Jefri decisions, looking at the number of the authorities considered and the court's approach to their construction and their application in the specific case. Setting aside the long analysis of precedents, in both the Court of Appeal and the House of Lords decisions, I shall attempt to examine the core of the rationale of the decisions.

In my opinion, the fundamental question on the basis of which the Prince Jefri case was judged was whether and to what extent the measures taken by KPMG to protect the confidential information possessed could be considered in the particular case as adequate to protect its confidentiality.

It should be emphasised that this question was placed in concreto in view of the adequacy of the particular Chinese wall that was adopted by KPMG in this specific case. Indeed the Court of Appeal considered the specific arrangements as adequate to protect the confidential information by adopting the Russell $v$ Tower Corporation test of three questions stated above. On the other hand, their Lordships rejected the Tower test and were of the view that the specific measures taken by KPMG were not in the particular case adequate to preserve the confidentiality of information.

The decision of the Court of Appeal does not leave any doubt as to the court's views on the adequacy of the Chinese wall, given the fact that the court expressed its satisfaction that the wall was sufficiently adequate 
to ensure that there was no real or appreciable risk of inadvertent disclosure of information.

On the other hand, although the House of Lords granted the injunction and restrained KPMG from acting in a situation of potential conflict, it did so not on the grounds that the Chinese wall is generally an ineffective means of compartmentalisation, but because the particular measures arranged by KPMG in the specific case were considered inadequate. May I note at this point that the ruling in the more recent case of Young $v$ Robson Rhodes ([1993] 3 All ER 524) affirmed this reading of the House of Lords decision.

Indeed, according to Lord Millett, the adequacy of the 'Project Lucy Wall' (as KPMG called its own Chinese wall) was undermined by various facts, such as the following:

(1) The fact that the Project Lucy Wall was established ad hoc, only when KPMG undertook this specific project and in knowledge of the conflict and the risk of communication of information between its two teams working in conflicting projects. On this I should express my disagreement with the reading of Lord Millett's view by Mr Justice Luddie in the Robson Rhodes decision, whereby the latter thought that Lord Millett said that:

'all that matters is whether the wall works and not whether it was erected before - as part of the firm's fabric - or at the very instance of the problem'

I would tend to think that Lord Millett wanted to clarify that when a wall is erected ad hoc this is a consideration leading to increased risk of disclosure of confidential information.

(2) The wall operated within one single department. This does not generally accord with the traditional concept of the wall being an establishment which separates different departments of the same establishment The bibliography on Chinese walls tends to agree as to the limited adequacy of a Chinese wall operating within one single department, in view of the apparent technical and procedural difficulties in separating teams within the same department, within a culture of people who are used to working together, cooperating and seeking each others' advice on everyday issues of work, and, after all, the inevitable risk of everyday communication and casual chat.

(3) It was established that a number of KPMG's employees had actually worked with both of the teams that were working on the conflicting projects and had thus effectively been transferred over the wall.

I would disagree with several commentators who have argued that Prince Jefri has not brought significant changes as far as the adequacy of the Chinese wall is concerned. My personal view is that the importance of the case is dual. On the one hand, the concept of the Chinese wall was for the first time judicially endorsed as an effective means of legal defence in connection with breach of fiduciary duties, as both the decision of the Court of Appeal directly, as well as the decision of the House of Lords indirectly by argumentum a contrario, endorse the concept of a permanently-established and properly-operating Chinese wall that effectively separates different departments of a firm. On the other hand, in the House of Lords decision, Lord Millett actually considered industry standards as to the proper construction and operation of the Chinese wall within a firm, giving an indication that the adequacy of a Chinese wall can and will be evaluated on the basis of certain standards crystallised in practice within a specific industry.

\section{Efficiency as a legal defence}

The question of whether the new Financial Services and Markets Act should provide specific guidance as to the proper construction and operation of the Chinese wall in order for it to be accepted by the courts as an effective means of legal defence is an issue that requires significant consultation with the financial services industry.

My own view is that the FSMA should endorse the Chinese wall as an efficient legal defence, by referring the evaluation of its practical adequacy to clearly set and identifiable standards, formulated in accordance with the practice of the financial services industry and incorporated in the new core conduct of business rules to be drafted further to the enactment of the act.

\section{George Barboutis}

Shearman \& Sterling

\section{Addendum}

In the article by Olosuji Elias entitled 'The impact of globalisation on human rights', Amicus Curiae, Issue 28, June 2000, pp. 19-23, the reference to Globalization and the Postmodern Turn on p. 23 should read: 'http://www.gseis.uc/ at p. 2'. 